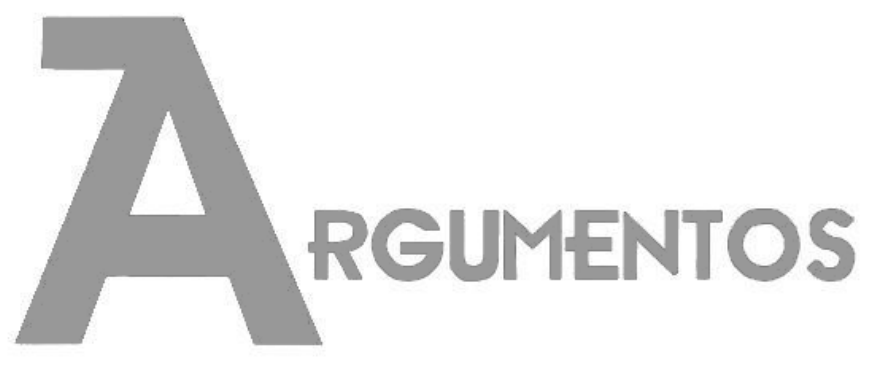

Vol. 18, n. 1, jan./jun. 2021 ISSN: 2527-2551 (online)

https://www.periodicos.unimontes.br/index.php/argumentos

\title{
Gênero e cidadania: reflexões sobre a participação política das mulheres no processo eleitoral de 2018 no Brasil
}

Licemar Vieira Melo ${ }^{1}$

Thaís da Rosa Alves ${ }^{2}$

Recebido em: 29/11/2019

Aprovado em: 01/06/2020

Resumo: Este artigo discute a cidadania na perspectiva específica de gênero, ao propor reflexões sobre a participação política das mulheres no processo eleitoral de 2018 no Brasil, em duas perspectivas: enquanto eleitoras - a partir de mobilizações nas redes sociais digitais e manifestações de rua em diversas cidades do país e no exterior - e enquanto candidatas a um cargo de representatividade política, pois naquela eleição houve um aumento, em relação ao pleito anterior, de cinquenta por cento da bancada feminina na Câmara Federal. Neste trabalho são contempladas reflexões em torno da construção histórica e consolidação da cidadania; da participação política das mulheres no Brasil; para depois discutir especificamente a participação das mulheres no processo eleitoral de 2018.

Palavras-chave: Cidadania, gênero, ciberativismo, processo eleitoral de 2018.

\section{Género y ciudadanía: reflexiones sobre la participación política de las mujeres en el processo electoral de 2018 en el Brasil}

Resumen: Este artículo aborda la ciudadanía em uma perspectiva específica de género, al proponer reflexiones sobre la participación política de las mujeres em el processo electoral de 2018 em Brasil, em dos perspectivas: como votantes - desde movilizaciones em redes sociales digitales y manifestaciones callejeras em varias ciudades del pais y del extranjeto, y como candidatos para um puesto de representación política, porque en esa elección hubo um aumento, em comparación com las elecciones anteriores, del cincuenta por ciento del banco feminino em la Cámara Federal. Em este trabajo se contemplan reflexiones sobre la construcción histórica y la consolidación de la ciudadanía; la participación política de las mujeres

\footnotetext{
${ }^{1}$ Jornalista, Mestre em Ciências Sociais Aplicadas, doutoranda no PPG em Ciências Sociais da Universidade do Vale do Rio dos Sinos (UNISINOS), São Leopoldo, Brasil. E-mail: licemarvm@gmail.com. ORCID: https://orcid.org/ 0000-0002-1140-0929.

${ }^{2}$ Licenciada em Ciências Sociais. Mestre em Ciências Sociais, doutoranda no PPG em Ciências Sociais da Universidade do Vale do Rio dos Sinos (UNISINOS), São Leopoldo, Brasil. E-mail: thaisalves1406@gmail.com. ORCID: https://orcid.org/0000-0002-8994-0247.
} 
Artigos | Gênero e cidadania: reflexões sobre a participação política das mulheres no processo eleitoral de 2018 no Brasil (MELO, Licemar Vieira; ALVES, Thaís da Rosa)

em Brasil; y luego discuta especificamente la participación de las mujeres en el processo electoral de 2018.

Palabras-clave: Ciudadanía, género, ciberactivismo, processo electoral de 2018.

\title{
Gender and citizenship: reflections about women's political participation in Brazil 2018 electoral process
}

\begin{abstract}
This article approaches citizenship in the specific gender perspective by proposing reflections on the political participation of women in the 2018 electoral process in Brazil, in two perspectives: a voters - of mobilizations on digital social networks and street protests in various cities, from the country and abroad - an as candidates for a position of political representation, because in that election there was an increase, compared to the previous elections, of fifty percent of the women's bank in the Federal Chanber. In this work, reflectons on the historical construction and consolidation of citizenship are contemplated; the political participation of women in Brazil; and then specifically discuss women's participation in the 2018 electoral process.
\end{abstract}

Keywords: Citizenship, gender, cyber-activism, 2018 electoral process.

\section{Introdução}

A conquista e a consolidação da cidadania é uma discussão frequente entre as Ciências Sociais, especialmente na área da Ciência Política. Esse artigo pretende lançar um olhar sobre essa temática numa perspectiva específica relacionada às questões de gênero. Nesse sentido, as discussões aqui apresentadas partem de uma análise das peculiaridades do recente processo eleitoral brasileiro de 2018 que, entre outros aspectos, evidenciou a participação política das mulheres em perspectivas distintas: enquanto eleitoras e enquanto representantes políticas, a partir da ampliação de espaço conquistado, se tomarmos por base a Câmara dos Deputados ${ }^{3}$.

Enquanto eleitoras, as mulheres se manifestaram através das redes sociais digitais $^{4}$ e de mobilizações em várias cidades brasileiras, assim como em algumas cidades no exterior, em setembro de $2018^{5}$, mês que antecedeu as eleições, assumindo

\footnotetext{
${ }^{3}$ A escolha pela análise da disputa de vagas na Câmara Federal pelas mulheres e não na outra casa legislativa, o Senado, se deve ao fato de que na Câmara eram 513 vagas em disputa, enquanto no Senado eram apenas 54 vagas.

${ }^{4}$ Exemplo disso foi o Movimento "Mulheres Unidas contra Bolsonaro" (PINHEIRO-MACHADO; BURIGO, 2018) que, na rede social Facebook através da campanha denominada \#EleNão publicava, nos meses que antecediam as eleições, mensagens contra o candidato a Presidente da República, Jair Bolsonaro. Em outra via, como reação a campanha \#EleNão foi criada a campanha \#EleSim nas redes sociais Facebook, Instragram e WhatsApp.

${ }^{5}$ Houve registro de manifestações de mulheres contrárias a candidatura de Jair Bolsonaro, no dia 29/09/2018, em 114 cidades do país e, também no exterior como em Lisboa, Londres, Nova York e Paris (ROSSI; CARNEIRO; GRAGNANI, 2018). No mesmo dia e no dia seguinte, 30/09/2018, foram registradas manifestações favoráveis ao referido candidato, em cidades como São Paulo, Belo Horizonte, Salvador, Vitória e Porto Alegre (UOL, 2018).
} 
Artigos | Gênero e cidadania: reflexões sobre a participação política das mulheres no processo eleitoral de 2018 no Brasil (MELO, Licemar Vieira; ALVES, Thaís da Rosa)

posicionamentos contrários ou favoráveis ao discurso conservador e liberal de um dos candidatos à Presidência da República, Jair Messias Bolsonaro, do Partido Social Liberal, que acabou sendo eleito em votação no segundo turno.

Por outro lado elas ampliaram o espaço de representatividade política, na Câmara Federal, na primeira eleição em que, além do cumprimento da cota de gênero, já estabelecida pela Lei Federal 12.034/2009 - que prevê que cada partido ou coligação deve preencher o mínimo de $30 \%$ e o máximo de $70 \%$ para candidaturas de cada sexo 6 - puderam contar com recursos financeiros para suas campanhas. Por determinação do Tribunal Superior Eleitoral, de maio de 2018, os recursos do Fundo Partidário destinado para campanhas eleitorais de mulheres devem ser proporcionais à presença feminina entre o total de candidatos. Ou seja, além da cota de gênero, estabelecida pela Lei Federal acima referida, houve, por determinação do TSE, destinação de recursos do Fundo Partidário para o financiamento das candidaturas das mulheres, além de destinação de tempo proporcional na propaganda eleitoral obrigatória?

Foi nesse contexto que as mulheres ampliaram em $50 \%$ a participação na Câmara Federal, passaram de 51 cadeiras, conquistadas nas eleições de 2014 - isso correspondia a $10 \%$ do total de cadeiras - para 77 cadeiras, em 2018 - que corresponde a $15 \%$ do total de cadeiras $^{8}$. Esse percentual atingido em 2018, apesar de minoritário, considerando o universo total de total de 513 cadeiras da Câmara Federal, corresponde a uma conquista de espaço das mulheres e um avanço no que se refere à representatividade política.

No que tange a cidadania cotejamos algumas reflexões em torno da construção histórica do conceito (CERQUIER-MANZINI, 2010; PACHECO, 2003; PINSKY e PINSKY, 2010), e da relação entre cidadania, Direitos Humanos e Democracia (LUNARDI e SECCO, 2010, TOURAINE, 1996), para, enfim, discutir a abrangência e complexidade desse conceito, no contexto contemporâneo.

\footnotetext{
${ }^{6}$ No contexto brasileiro os $30 \%$ são destinados às mulheres, já que, historicamente o exercício do poder político ficou restrito majoritariamente aos homens.

${ }^{7}$ O TSE determinou que 30\% dos recursos do Fundo Especial de Financiamento de Campanha, criado a partir de uma minirreforma eleitoral, de 2017 , e $30 \%$ do tempo de propaganda eleitoral fossem destinados às candidaturas femininas. Disponível em: http://www.tse.jus.br/imprensa/noticiastse/2018/Maio/fundo-eleitoral-e-tempo-de-radio-e-tv-devem-reservar-o-minimo-de-30-paracandidaturas-femininas-afirma-tse. Acesso: 02 mai. 2020.

${ }^{8}$ Disponível em: https://www.camara.leg.br/noticias/552996-mulheres-ocupam-mais-cadeiras-e-postosde-comando-na-camara-dos-deputados/ Acesso: 02 mai. 2020.
} 
Artigos | Gênero e cidadania: reflexões sobre a participação política das mulheres no processo eleitoral de 2018 no Brasil (MELO, Licemar Vieira; ALVES, Thaís da Rosa)

Sobre a participação política das mulheres, no Brasil, apresentamos marcos referenciais que demarcam a conquista da cidadania, a partir da luta pelos direitos políticos, como o reconhecimento ao direito ao voto das mulheres nas eleições, na década de 1930, e, mais recentemente, a partir da Lei Federal 12.034 de 2009, ficou estabelecido um mínimo de 30\% e máximo de $70 \%$ para candidaturas de cada sexo esse marco, especificamente representa um avanço, por estipular uma cota de gênero, um percentual mínimo de candidatos por sexo, mas não estabelece uma equidade na disputa eleitoral já que esse percentual mínimo de candidaturas (30\%) é destinado às mulheres.

Num terceiro momento voltamos as discussões especificamente, para a participação das mulheres no processo eleitoral de 2018 para, nas considerações finais, apresentarmos alguns apontamentos a partir do cruzamento de informações referentes a esse fenômeno e os pressupostos teóricos que embasam as discussões referentes a cidadania e a participação política feminina no Brasil.

\section{Cidadania}

Abordar o tema cidadania exige que se perceba a construção e abrangência do termo que aparece de forma distinta em diferentes períodos históricos, tendo como marcos referenciais as experiências vividas na Grécia Antiga, no período que antecedeu a Revolução Francesa e na contemporaneidade, a partir da Declaração dos Direitos Humanos, em 1948 (CERQUIER-MANZINI, 2010; LUNARDI E SECCO, 2010; PACHECO, 2003; PINSKY e PINSKY, 2010).

Nessa breve discussão sobre o tema a proposta é contemplar um resgate histórico da construção desse conceito, bem como contemplá-lo a luz dos direitos humanos, das diferentes concepções de Estado, vigente nos distintos períodos históricos, e, relacioná-lo à democracia.

A condição de cidadania se originou na Grécia Antiga, numa referência aos direitos políticos relacionados à participação na vida pública. Foi o filósofo grego, Aristóteles, quem definiu que 
O que constitui propriamente o cidadão, sua qualidade propriamente característica, é o direito de voto nas Assembléias (sic) e de participação no exercício de poder público em sua pátria. (....). Não é a residência que constitui o cidadão: os estrangeiros e os escravos não são 'cidadãos', mas sim 'habitantes. (....) Ora chamamos cidadão quem quer que seja admitido nessa participação e é por ela, principalmente, que o distinguimos de qualquer outro habitante (ARISTÓTELES, 1998, p. 42).

Inicialmente, conforme Giovani Lunardi e Márcio Secco, numa referência ao pensamento de Danilo Zolo (1994), a cidadania "não significou nada mais que a diferença entre o cidadão e o estrangeiro do ponto de vista da titularidade de um certo número de direitos e deveres" (ZOLO apud LUNARDI e SECCO, 2010, p. 175-6).

A cidadania surge, portanto, relacionada "à capacidade dos homens exercerem direitos e deveres do cidadão (direitos políticos)" (CERQUIER-MANZINI, 2010, p. 23). Violaine Sebillotte Cuchet (2015) enfatiza que, no contexto da Antiguidade, a relação entre cidadania e gênero é destacada, ao analisar as experiências vivenciadas na Grécia Antiga, especificamente na cidade de Atenas, enfatiza que, apesar de não se ter conhecimento da existência de nenhuma regra expressa, havia um entendimento tácito de que a participação política e deliberação nas assembleias eram atividade restritas aos homens. Cuchet menciona registros que comprovariam a exclusividade dos homens enquanto atores sociais que protagonizavam as discussões e deliberações políticas, naquele contexto. As mulheres, segundo a autora, até poderiam participar das Assembleias, mas apenas sob a tutela de um homem - pai, esposo, ou irmão, por exemplo - com a incumbência de representá-las.

A partir do entendimento da cidadania como os direitos e deveres políticos exercidos em Atenas, na Grécia Antiga, essa nasceu restrita aos homens livres, já que as mulheres, de antemão, foram excluídas desse processo.

$\mathrm{Na}$ modernidade, com o aperfeiçoamento das ideias e das instituições no ocidente e do desenvolvimento dos direitos humanos e fundamentais a concepção inicial e restritiva da cidadania é ampliada, passando a ser entendida como o "pertencimento a uma comunidade e aos direitos dela decorrentes" (LUNARDI e SECCO, 2010, p. 176). Isso, conforme os autores, relaciona a cidadania a concepção de direitos, a partir da formalização que se dá pela Declaração Francesa de 1789 - documento que 
Artigos | Gênero e cidadania: reflexões sobre a participação política das mulheres no processo eleitoral de 2018 no Brasil (MELO, Licemar Vieira; ALVES, Thaís da Rosa)

apresenta os direitos do homem e do cidadão9 ${ }^{9}$, elaborado no contexto da Revolução Francesa, que estabelece

Art. 11으 - A livre comunicação das idéias (sic) e das opiniões é um dos mais preciosos direitos do homem. Todo cidadão pode, portanto, falar, escrever, imprimir livremente, respondendo, todavia, pelos abusos desta liberdade nos termos previstos na lei (DECLARAÇÃO UNIVERSAL DE DIREITOS DO HOMEM E DO CIDADÃO, 1789)

Foi, portanto, na Europa saída do feudalismo, que o grupo de valores hoje chamado direitos civis, se articulam e ganham legitimidade social. Surge, então, o cidadão como o indivíduo ao qual se reconhece o direito à liberdade e à igualdade perante a lei. (PACHECO, 2003).

Esse é um novo patamar da cidadania que "pela primeira vez na história uma proclamação outorga a titularidade dos direitos à pessoa pelo mero fato de sê-lo, independentemente de haver nascido ou não em uma determinada estrutura social" (ARBÓS apud LUNARDI E SECCO, 2010, p. 177) ${ }^{10}$.

É nesse contexto, de incorporação dos direitos civis à cidadania, através da Declaração dos Direitos do Homem e do Cidadão, que começa a haver uma associação entre ela, a cidadania, e os direitos humanos, direitos esses que, no referido contexto, correspondem as liberdades individuais e são entendidos como de primeira geração

São consagrados nas primeiras constituições escritas e se referem se relacionam ao "pensamento liberal individualista do séc. XVII". Se referem aos direitos civis e políticos. São "os 'direitos de defesa' do indivíduo em relação ao Estado, que restringem o campo de intervenção deste, e garantem o espaço de autonomia individual (...) valorizando as liberdades abstratas do homem singular, inserido na sociedade" (LUNARDI e SECCO, 2010, p. 188).

\footnotetext{
${ }^{9}$ Destaque-se que, em contraposição a Declaração dos Direitos do Homem e do Cidadão, Marie Gouze (1748-1993), sob o codinome de Olympe de Gouges, apresentou, à Assembleia da França - em pleno séc. XVIII, no contexto da Revolução Francesa - uma "Declaração dos Direitos da Mulher e da Cidadã", através da qual defendia a igualdade de direitos para as mulheres, razão pela qual foi condenada à morte na guilhotina, acusada de ser contra revolucionária. Disponível em: http://www.direitoshumanos.usp.br/index.php/Documentos-anteriores-\%C3\%A0cria\%C3\%A7\%C3\%A3o-da-Sociedade-das-Na\%C3\%A7\%C3\%B5es-at\%C3\%A9-1919/declaracao-dosdireitos-da-mulher-e-da-cidada-1791.html. Acesso: 03 mai. 2020.

10 Tal processo, no entanto, não foi homogêneo. No Brasil, especificamente, foi preciso muita luta e anos decorridos para a cidadania ser desvencilhada da estrutura social.
} 
Artigos | Gênero e cidadania: reflexões sobre a participação política das mulheres no processo eleitoral de 2018 no Brasil (MELO, Licemar Vieira; ALVES, Thaís da Rosa)

No século XX, contexto pós II Guerra Mundial e diante do progresso técnico proporcionado pela industrialização da sociedade ocidental, os indivíduos passam a reivindicar a socialização dos benefícios que ela produziu. No campo do imaginário social, os princípios de liberdade e de igualdade, ecoados a partir da Revolução Francesa, são ampliados para o campo dos chamados direitos sociais, tendo como marco a Declaração Universal dos Direitos Humanos, adotada e proclamada em Assembleia das Nações Unidas em 10 de dezembro de 1948.

Entre os direitos contemplados na declaração estavam os direitos: à vida e nacionalidade; à liberdade de pensamento, consciência e religião; ao trabalho e a educação, à alimentação e habitação e a fazer parte de um governo. Além disso a declaração também reconheceu os direitos e as liberdades, sem qualquer distinção raça, cor, sexo, entre outras.

Lunardi e Secco (2010, p. 189) denominam essa como sendo a segunda geração de direitos humanos, correspondente ao que os autores se referem como 'direitos de igualdade'.

As transformações político-institucionais ocorridas no deslocamento - do Estado Liberal ao Estado Social - e sua crise - na dinâmica dos conflitos e novas demandas sociais promoveram a positivação da geração/dimensão dos direitos (....) caracterizada por outorgar direitos a prestações sociais estatais, como assistência social, saúde, educação, trabalho, etc. Trata-se dos chamados 'direitos sociais, econômicos e culturais'. (...). São direitos coletivos ou de coletividades, introduzidos nas distintas formas de Welfare State".

No pensamento dos autores há uma referência aos modelos (ideológicos) do Estado e a influência desses sobre a cidadania, aspectos esses abordados na sequência.

\section{A cidadania nos diferentes modelos de regulação de Estado}

Quando no século XVIII ocorre a ascensão de um Estado Liberal, os direitos civis são incorporados à cidadania, que já contemplava, desde a Antiguidade, os direitos políticos. Entendidos como direitos civis estão aqueles relativos às liberdades individuais - como de opinião e expressão - e a igualdade, por exemplo, perante a lei. 
Artigos | Gênero e cidadania: reflexões sobre a participação política das mulheres no processo eleitoral de 2018 no Brasil (MELO, Licemar Vieira; ALVES, Thaís da Rosa)

Já no século XX, com o surgimento do Welfare State - Estado de Bem-estar Social - nos países industrializados, após a II Guerra Mundial, há uma postura protecionista do Estado, ator social que toma para si a responsabilidade da promoção social, e, nesse panorama há a incorporação dos direitos sociais à cidadania, o que representa a ampliação, completude e complexidade desse conceito, atingidas na contemporaneidade.

A relação entre o Estado de Bem-estar Social e a cidadania é referida por Bourdieu (2014), quando esse autor afirma que o Welfare State é "um Estado que dá ao cidadão aquilo a que ele tem direito, isto é, mais que os direitos do cidadão, os direitos humanos, o direito ao trabalho, o direito à saúde, o direito à segurança, etc. O cidadão é, portanto, definido por seus direitos (...)" (BOURDIEU, 2014, p. 620).

Portanto, é no século XX que se concebe o cidadão como o indivíduo imbuído de direitos políticos, civis e sociais (CERQUIER-MANZINI, 2010, LUNARDI E SECCO, 2010, PACHECO, 2003 E PINSKY E PINSKY, 2010).

No contexto atual, em que o Estado para promover os direitos de cidadania, principalmente os sociais age, segundo Giddens (2001) e Kliksberg (2002) em cooperação com diversos atores, ser cidadão significa

[...] ter direito à vida, à liberdade, à propriedade, à igualdade perante a lei: é, em resumo, ter direitos civis. É também participar no destino da sociedade, votar, ser votado, ter direitos políticos. Os direitos civis e políticos não asseguram a democracia sem os direitos sociais, aqueles que garantem a participação do indivíduo na riqueza coletiva: o direito à educação, ao trabalho, ao salário justo, à saúde, a uma velhice tranqüila (sic). Exercer a cidadania plena é ter direitos civis, políticos e sociais, fruto de um longo processo histórico que levou a sociedade ocidental a conquistar parte desses direitos (PINSKY e PINSKY, 2010, p. 09).

Esses mesmos autores, ao reforçar que a cidadania não é um conceito estanque, mas histórico, enfatizam que a mesma muda não apenas conforme o tempo, já que é uma construção histórica, mas, também, conforme o espaço ${ }^{11}$.

É muito diferente ser cidadão na Alemanha, nos Estados Unidos ou no Brasil (para não falar dos países em que a palavra é tabu), não apenas pelas regras

\footnotetext{
${ }^{11}$ Bourdieu (2014) também faz referência a esse aspecto quando contempla os diferentes modelos de cidadania vivenciados na França, onde a questão da territorialidade é determinante, daquele predominante na Alemanha, em que as questões culturais são as que se sobrepõem.
} 
que definem quem é ou não titular da cidadania (por direito territorial ou de sangue), mas também pelos direitos e deveres distintos que caracterizam o cidadão em cada um dos Estados-nacionais contemporâneos. (PINSKY e PINSKY, 2010, p. 09).

Isso, porque, em cada lugar a relação específica entre o Estado e a sociedade, que se dá de maneira diferenciada, vai influenciar, diretamente, na cidadania, ou seja, na garantia do arcabouço que representa os direitos políticos, civis e sociais.

Cabe destacar, todavia, que apesar da construção, ampliação e consolidação do conceito de cidadania ter se dado ao longo da história e se concretizado de maneira diferente, nos distintos espaços, isso não significa que todos os direitos atrelados à condição de cidadania tenham sido, ao longo do tempo e em diferentes espaços, garantidos as mulheres. Um exemplo disso é o próprio direito a participação política das mulheres, objeto de análise nesse artigo, que na Antiguidade deu origem a construção do que hoje se entende por cidadania, que só passou a ser reivindicado e estabelecido, no Brasil, a partir do século XX, com o estabelecimento do direito ao voto das mulheres, na década de 1930.

\section{Cidadania, democracia e a participação política das mulheres}

Depois de brevemente tentar percorrer a trajetória histórica que origina a discussão atual da cidadania; de percebê-la como diretamente relacionada aos direitos humanos, especificamente a partir da Declaração dos Direitos do Homem e do Cidadão, no século XVIII e de contemplar as mudanças desse conceito a partir dos distintos modelos ideológicos do Estado - Liberal, na modernidade e Social, na contemporaneidade; resta apenas destacar que a discussão desse tema, pela complexidade e abrangência do mesmo, só é pertinente e se justifica, em países de regime democrático, pois a democracia

[...] não se reduz a procedimentos porque representa um conjunto de mediações entre a unidade do Estado e a multiplicidade dos atores sociais. É preciso que sejam garantidos os direitos fundamentais dos indivíduos; é preciso também que estes se sintam cidadãos e participem da construção da vida coletiva. Portanto é preciso que os dois mundos - o Estado e a sociedade civil - que devem permanecer separados, fiquem ligados um ao outro pela representatividade dos dirigentes políticos. Essas três dimensões 
Artigos | Gênero e cidadania: reflexões sobre a participação política das mulheres no processo eleitoral de 2018 no Brasil (MELO, Licemar Vieira; ALVES, Thaís da Rosa)

da democracia - respeito pelos direitos fundamentais, cidadania e representatividade política dos dirigentes - completam-se aliás é sua interdependência que constitui a democracia. (TOURAINE, 1996, p. 43)

Após essas reflexões em torno da cidadania, esse trabalho se direciona para abordar, especificamente, um viés da cidadania, que se refere à participação política. Nesse caso específico a discussão se volta para a participação política das mulheres, no contexto brasileiro.

Como já mencionado o conceito de cidadania surgiu a partir da experiência vivida na Grécia Antiga e, nesse princípio, se restringiu aos direitos políticos de participação dos homens livres nas assembleias que aconteciam nas praças públicas - àgoras - locais em que se decidiam os destinos daquela sociedade (ARISTÓTELES, 1998; CERQUIERMANZINI, 2010; LUNARDI e SECCO, 2010; PINSKY e PINSKY, 2010).

Nesse momento propomos um olhar da cidadania, nessa mesma perspectiva, de participação política, acrescentando duas especificidades: a de gênero, no contexto brasileiro.

Compreendemos, assim como Joan Scott $(1995$, p. 86) que gênero corresponde a um "[...] elemento constitutivo das relações sociais baseadas nas diferenças percebidas entre os sexos e [...] o gênero é uma forma primária de dar significado às relações de poder". Ou seja, homens e mulheres são produtos da realidade social e não decorrências da anatomia dos seus corpos e, tais realidades estão localizadas na sociedade de forma hierárquica, privilegiando ao longo da história o gênero masculino.

A maneira como a constituição da cidadania foi sendo desenhada no Brasil, influenciou a forma como as mulheres conseguiram estabelecer alguns de seus direitos a partir da ressignificação dos princípios feministas, desde uma ótica ocidental de democracia liberal, juntamente com os valores e normas de políticas locais, como o personalismo, o patrimonialismo e a hierarquia. (BONETTI, FONTOURA, MARINS, 2008).

Segundo as autoras, esta característica peculiar localiza a cidadania feminina desde a posição ocupada pelas mulheres na família, “[...] ou seja, em vez das mulheres serem investidas de direitos como sujeitos em si, elas somente são detentoras de direitos na medida em que estão ligadas ao ente família" (BONETTI; FONTOURA, MARINS, 2008, p. 202). 
Artigos | Gênero e cidadania: reflexões sobre a participação política das mulheres no processo eleitoral de 2018 no Brasil (MELO, Licemar Vieira; ALVES, Thaís da Rosa)

Para compreender como se deu algumas das principais conquistas do movimento feminista e de mulheres no Brasil, a condição de cidadãs, cabe retomar alguns marcos referenciais.

A mobilização de mulheres brasileiras data ainda no século XIX, principalmente pela influência de ideais libertários que circulavam pelo país que influenciaram os movimentos abolicionistas e republicanos, porém, foi na primeira metade do século XX que as mulheres se organizaram diante de uma demanda específica: o direito ao voto (BLAY, 2017).

A luta pela conquista dos direitos políticos das mulheres é considerada como pertencente à "primeira onda" 12 do feminismo brasileiro, junto das sufragistas, mais ligadas às camadas da elite, outras mulheres mobilizavam-se em torno de pautas como a emancipação feminina e o direito à educação, como as anarquistas e as jornalistas feministas (BONETTI; FONTOURA; MARINS, 2008).

Apenas em 1932 as mulheres conquistam o direito ao voto, o que propiciou a candidatura e a eleição de algumas mulheres que passaram a ingressar nos partidos políticos da época (BLAY, 2017). Porém, ao constatarem que o poder do voto não fora o suficiente para mudanças mais profundas na sociedade, o movimento feminista brasileiro se desmobilizou.

Foi no período da ditadura militar brasileira que o feminismo brasileiro ${ }^{13}$ ressurge tendo como pauta os direitos das mulheres e o questionamento do papel das mulheres na sociedade, é neste período também que uma pluralidade de movimentos de mulheres surge, principalmente aqueles formados por mulheres das camadas populares (SINGER, 1983), demarcando assim, a "segunda onda"14..

\footnotetext{
${ }^{12}$ Alguns estudos demarcam as diferentes gerações dos movimentos feministas como "ondas". Sendo assim, a primeira onda foi demarcada pela luta das mulheres ligadas ao movimento sufragista que nasceu na Europa no século XVIII. Embora a denominação de "ondas" seja amplamente utilizada como forma de elucidar as modificações em diferentes épocas, esta noção também é criticada pelo fato de que se pressupõe que o feminismo se configura como um movimento homogêneo, quando na verdade é um movimento plural, ou seja, existem movimentos feministas. Além disso, estas "ondas" são demarcadas a partir do movimento feminista hegemônico formado por mulheres brancas, heterossexuais, oriundas da classe média e intelectualizadas. (LOZANO, 2010).

${ }^{13}$ Aqui a utilização do feminismo brasileiro no singular deve-se ao fato de que, neste período, era um grupo homogêneo de mulheres que se denominavam como parte do movimento feminista (SINGER, 1983).

${ }^{14}$ A "segunda onda" ou segunda geração do feminismo corresponde aos anos de 1960 e 1970, quando surgem as consideradas teorias clássicas feministas, iniciando-se seu período moderno. É também neste período que outras correntes políticas e teóricas feministas surgem como crítica ao movimento feminista
} 
Artigos | Gênero e cidadania: reflexões sobre a participação política das mulheres no processo eleitoral de 2018 no Brasil (MELO, Licemar Vieira; ALVES, Thaís da Rosa)

Ligadas às Comunidades Eclesiais de Base (CEBs), as mulheres de camadas populares participavam de organizações comunitárias, os "Clubes de Mães", foram nestes espaços que elas idealizaram alguns movimentos políticos de nível nacional com grande destaque no período do regime militar, como o Custo de Vida; o Movimento de Luta por Creches e o Movimento Feminino pela Anistia (ALVAREZ, 1988).

Segundo Sonia Alvarez (1988), durante a década de 1970, os movimentos pelo Custo de Vida e de Luta por Creches localizavam-se nas periferias urbanas das grandes cidades. O primeiro consistia na mobilização de donas de casa da periferia que denunciavam que o aumento do custo de vida acabava por agravar os problemas da população pobre, como transporte, saúde e alimentação que eram precários. O segundo era uma iniciativa das mulheres da classe trabalhadora que não tinham lugar adequado para deixarem seus filhos enquanto cumpriam sua jornada de trabalho. Ambas as mobilizações nasceram e se desenvolveram nos movimentos de base.

Já o Movimento pela Anistia era formado por mulheres que tiveram seus pais, filhos e maridos banidos ou presos pelo regime militar. De acordo com Eva Blay (1988), o movimento questionava a ação do Estado que retirou o direito à cidadania de certos indivíduos, sendo assim, o mesmo não se localizava na luta pela igualdade de recursos econômicos ou sociais como os dois movimentos anteriores.

Enquanto as mulheres de camadas populares possuíam pautas voltadas para a garantia de direitos sociais básicos, as feministas traziam como principais pautas tendências do feminismo internacional ao reivindicarem o reconhecimento das mulheres como sujeitos políticos, sendo assim, a agenda feminista brasileira abarcava o enfrentamento à violência contra as mulheres, principalmente aquela cometida no âmbito doméstico, a promoção à saúde da mulher e a defesa dos direitos reprodutivos e sexuais (BLAY, 1988).

Como afirma Eva Blay (2017), no período do regime militar, as mulheres organizadas mantiveram-se ativas e resistentes ao sistema político vigente, porém, suas demandas foram desprezadas pelos partidos políticos da época, inclusive nos considerados de esquerda, como o Partido Comunista Brasileiro (PCB). 
Artigos | Gênero e cidadania: reflexões sobre a participação política das mulheres no processo eleitoral de 2018 no Brasil (MELO, Licemar Vieira; ALVES, Thaís da Rosa)

É apenas com a abertura política que as mulheres começam a ponderar a arena política como um espaço para visibilizar suas pautas na passagem para a redemocratização. Algumas mulheres passam a considerar o ingresso e a candidatura através dos novos partidos políticos que começam a surgir em meados dos anos de 1980. É neste período que é criado o Conselho Nacional dos Direitos das Mulheres (CNDM), em 1985, importante articulador no processo da Constituição de 1988 que garantiu importantes avanços na construção da cidadania das mulheres no Brasil ao garantir a igualdade formal entre homens e mulheres (BONETTI; FONTOURA; MARINS, 2008).

\section{O período democrático: as cotas parlamentares e as redes feministas}

No período democrático um novo marco é instaurado na mobilização das mulheres. A partir de uma agenda internacional que buscava promover a efetivação dos direitos humanos e movidas pela busca do reconhecimento da mulher como sujeitos de direitos, os movimentos feministas e de mulheres passaram a discutir em torno dos direitos humanos das mulheres como forma de garantir o exercício da cidadania e dos direitos sociais das mulheres, o tema foi destaque após a II Conferência Internacional de Direitos Humanos, realizado em Viena no ano de 1993, no qual "Passou-se a difundir que a violência é uma das mais perversas violações dos direitos humanos das mulheres [...]." (BONETTI; FONTOURA; MARINS, 2009, p. 206).

A politização da violência contra as mulheres foi uma das formas encontradas por parte dos movimentos que não estavam inseridos em partidos políticos para garantir a responsabilização do Estado perante a proteção igual entre homens e mulheres, neste sentido, diversas Organizações não-governamentais passam a surgir no país aliando práticas de gênero e direito (JELIN, 1994).

No ano de 1995, ocorreu a IV Conferência Mundial da Mulher em Beijing, este evento é considerado uma importante referência para a construção da cidadania das mulheres, não apenas por ser nesta ocasião que há a inclusão de ações de enfrentamento à violência contra as mulheres no Plano Nacional de Direitos Humanos (PNDH I), mas também por ter sido neste momento que se passou a discutir a 
Artigos | Gênero e cidadania: reflexões sobre a participação política das mulheres no processo eleitoral de 2018 no Brasil (MELO, Licemar Vieira; ALVES, Thaís da Rosa)

desigualdade da participação feminina na representação política e se propôs políticas afirmativas para reverter esta situação (ALVES et al, 2017).

No Brasil, no mesmo ano, são adotadas leis ${ }^{15}$ que buscam garantir a participação das mulheres nos parlamentos. Atualmente, $30 \%$ é o percentual mínimo e $70 \%$ o máximo, estabelecido pela Lei Federal 12.034/2009, para candidaturas de cada sexo; o mínimo, entretanto, acaba sendo destinado as candidaturas das mulheres já que, no Brasil, historicamente, o exercício do poder político ficou restrito, majoritariamente, aos homens. É o que assinalaram Lúcia Avelar e Patrícia Rangel (2017), quando afirmam que a representação eleitoral das mulheres não garante que há de fato uma inclusão democrática das mulheres, visto que, mesmo com tais iniciativas, o número de candidatas eleitas ainda é modesto ${ }^{16}$. A exclusão das mulheres na política representativa não é uma questão do eleitorado, já que

A principal razão do problema está em uma 'lei de cotas' inadequada e nos partidos políticos que não conseguem abandonar suas práticas misóginas. São os políticos do sexo masculino que controlam os principais cargos dentro dos partidos e os espaços públicos de poder. Controlam também os recursos financeiros, o processo de escolha de candidaturas e a distribuição de tempo de propaganda gratuita. (ALVES et al, 2017, p. 50).

Ademais, segundo Luis Felipe Miguel (2014), existe um "essencialismo" ao se fazer implícito de que as mulheres eleitas responderão a interesses idênticos apenas pelo fato de serem mulheres, visto que o fato de integrarem o mesmo grupo não significa que todas as mulheres que chegam aos espaços políticos de poder irão possuir o compromisso com as pautas relacionadas aos movimentos de mulheres.

Todavia, existem algumas iniciativas, como a suprapartidária Bancada Feminina que tem como finalidade garantir a aprovação de determinadas propostas que versem sobre os direitos e a cidadania das mulheres (AVELAR; RANGEL, 2017).

Uma mudança considerável, em 2018, é o fato de que, pela primeira vez as candidatas mulheres puderam contar com recursos financeiros para suas campanhas,

\footnotetext{
${ }^{15}$ São elas, respectivamente: lei n. 9.100/1995, lei 9.504/1997 e lei n.12.034/2009.

${ }^{16}$ De acordo com o ranking da Inter-Parliamentary Union (IPU), o Brasil ocupou, em 2015, a posição 151ㅇ, isto significa que o país possui uma das piores colocações em se tratando de representação parlamentar de mulheres, ficando atrás, inclusive, de países árabes. (ALVES et al, 2017).
} 
Artigos | Gênero e cidadania: reflexões sobre a participação política das mulheres no processo eleitoral de 2018 no Brasil (MELO, Licemar Vieira; ALVES, Thaís da Rosa)

provenientes do Fundo Partidário e de tempo na propaganda política obrigatória, a partir de uma determinação do Tribunal Superior Eleitoral, de maio de 2018.

Apesar do período democrático não ter garantido a plena participação das mulheres em todos os espaços de poder, os anos de 1990 e 2000 representou um avanço profundamente relevante na articulação de mulheres, possibilitando o diálogo e a negociação com o Estado, principalmente a partir do primeiro mandato do presidente Lula (2003 - 2006) a partir da consolidação de redes feministas.

Estas redes, dotadas de um alto grau de organização e institucionalização, buscam promover ações e parcerias com as organizações do Estado e realizar o monitoramento parlamentar através da prática da advocacy ${ }^{17}$. Possuindo temas diversos, que passam desde uma reforma do sistema político à legalização do aborto, estas redes de representação extraparlamentar possuem como foco influenciar determinadas ações políticas, portanto, mesmo não tendo sido "eleitas", estas mulheres participam ativamente do espaço institucional pressionando para a criação e implementação de políticas públicas e leis em prol dos direitos das mulheres.

Contudo, esta forma como os movimentos feministas e de mulheres vem atuando na esfera pública está se modificando há alguns anos. Outras estratégias de atuação estão surgindo, principalmente com a utilização dos meios digitais, em especial as redes sociais, para a criação de diversos temas e mobilizações inerentes às mulheres, como as campanhas "Chega de Fiu-Fiu"18 e \#Meuprimeiroassédio ${ }^{19}$, entre outras, que possuem como principal foco o compartilhamento de depoimentos. Essa nova forma de mobilização, contemporânea, que acontece a partir da internet tem sido denominada de ciberativismo, que corresponde "a práticas comunicacionais que, utilizando plataformas, redes e suportes digitais, sobretudo na internet, visam entrosar

\footnotetext{
${ }^{17}$ A advocacy consiste em uma "ação coletiva, pública e política, em defesa dos direitos das mulheres, que tem por finalidade democratizar a esfera pública e conquistar mais justiça e igualdade" (AVELAR; RANGEL, 2017, p. 281).

${ }^{18}$ A campanha "Chega de Fiu-Fiu" foi criada pela ONG feminista Think Olga em 2013. A mesma se mobiliza pelo combate ao assédio sexual contra as mulheres em espaços públicos. Recentemente foi lançado o documentário com o mesmo nome da campanha que contou com financiamento coletivo virtual, o crowdfunding.

${ }^{19}$ A hashtag também é uma iniciativa da ONG Thing Olga e surgiu em 2015 após um episódio do reality show de culinária "Master Chef Junior", no qual uma das participantes, então com 12 anos, recebeu diversos comentários em suas redes sociais de cunho sexual, a partir desta campanha, diversas mulheres compartilharam em suas redes sociais suas histórias na qual relataram a primeira vez que foram assediadas sexualmente.
} 
Artigos | Gênero e cidadania: reflexões sobre a participação política das mulheres no processo eleitoral de 2018 no Brasil (MELO, Licemar Vieira; ALVES, Thaís da Rosa)

e dar maior visibilidade a lutas no interior da sociedade" (EISENBERG, 2015, p. 131).

Essas lutas começam no espaço virtual mas não necessariamente ficam restritas a ele. Esse foi o caso da campanha eleitoral de 2018, quando as manifestações de mulheres na internet, via redes sociais, ganharam as ruas das principais cidades brasileiras e algumas cidades no exterior.

\section{As mulheres e o processo eleitoral de 2018 no Brasil}

Depois de contemplarmos as discussões referentes a cidadania e a participação política das mulheres, no Brasil, direcionamos essa discussão especificamente para o processo eleitoral de 2018 que, sob a ótica da participação feminina pode ser analisado sob duas perspectivas: a primeira, a partir da consideração do papel delas enquanto eleitoras, e a segunda, a representatividade política delas a partir, por exemplo, da análise das vagas conquistadas no Legislativo Federal, especificamente na Câmara dos Deputados.

\section{As mulheres enquanto eleitoras}

Buscar analisar a participação política das mulheres, enquanto eleitoras, no processo eleitoral brasileiro de 2018, especificamente na fase que antecedeu as votações de primeiro e segundo turnos, para o cargo de Presidente da República, naturalmente, por ter sido uma característica marcante desse pleito, uma discussão se sobrepõe: as mobilizações a partir da internet, numa perspectiva de ciberativismo feminino ${ }^{20}$. Seja pelas redes sociais de computadores como o Facebook, o Twitter ou o Instagram, ou mesmo por aplicativos de mensagens de celular como o WhatsApp; houve publicação e compartilhamento de mensagens, com posicionamentos políticos assumidos pelas mulheres, cidadãs comuns ou personalidades públicas - como artistas de televisão, jornalistas, cantoras - que se declararam contrárias ou favoráveis a Jair Messias Bolsonaro, candidato a Presidência da República pelo Partido Social Liberal PSL.

\footnotetext{
${ }^{20}$ Optou-se por usar a expressão "ciberativismo feminino" e não feminista pois a questão que aqui se trata é a mobilização política das mulheres, através da internet, independente de serem ou não adeptas ao movimento feminista.
} 
Artigos | Gênero e cidadania: reflexões sobre a participação política das mulheres no processo eleitoral de 2018 no Brasil (MELO, Licemar Vieira; ALVES, Thaís da Rosa)

O motivo que teria desencadeado as manifestações na internet que, em alguns momentos, se estenderiam as ruas de muitas cidades do pais e de algumas cidades, no exterior, no mês que antecedeu as eleições - setembro de 2018 - seriam as declarações polêmicas que Jair Bolsonaro, candidato ao cargo de Presidente da República, havia feito recentemente, enquanto exercia o mandato de Deputado Federal, em relação às mulheres, aos homossexuais, aos negros, aos índios, além de uma reverência, durante a votação do impeachment da Presidenta Dilma Rousseff, em 2016, a um militar, considerado torturador, na época da ditadura, no Brasil.

Como iniciativa de ciberativismo feminino contrária a candidatura de Jair Bolsonaro, surgiu, em agosto de 2018, na rede social Facebook o Movimento "Mulheres Unidas Contra Bolsonaro" (PINHEIRO-MACHADO; BURIGO, 2018), que através de uma campanha, denominada \#EleNão publicava mensagens contra o candidato Jair Bolsonaro, do PSL, que eram compartilhadas nas redes sociais digitais. Segundo um estudo realizado pelo Laboratório de Estudos sobre Imagem e Cibercultura da Universidade Federal do Espírito Santo (UFES), em setembro de 2018, às hastags contra o candidato Jair Bolsonaro - \#elenão, \#elenunca, \#elejamais; \#mulherescontrabolsonaro; \#mucbvive - atingiram 1 milhão de participantes (BECKER, 2018).

If Mulheres unidas contra $\circ$ Bolson $x+$

$\leftarrow \rightarrow \mathrm{C} \oplus \mathrm{https://www.facebook.com/mulherescontraofascismo}$

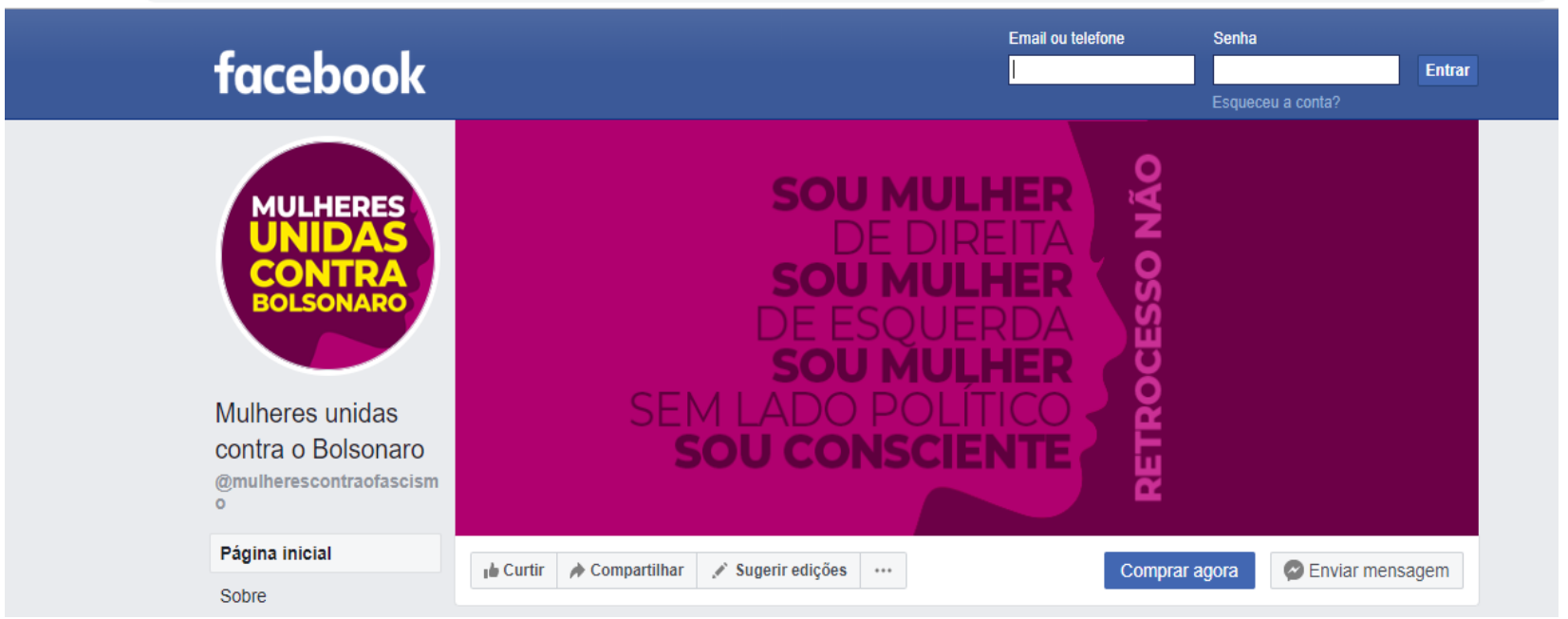

Imagem 1: Página de abertura da página "Mulheres Unidas contra Bolsonaro"

Fonte: Facebook 
Por outro lado, também através das redes sociais, houve a criação de uma página na rede social Facebook, chamada "Mulheres com Bolsonaro". Em reação a campanha \#Elenão as apoiadoras de Bolsonaro lançaram a campanha \#Elesim, que, além do Facebook, também tomou conta de outras redes sociais como o Instagram e o WhatsApp.

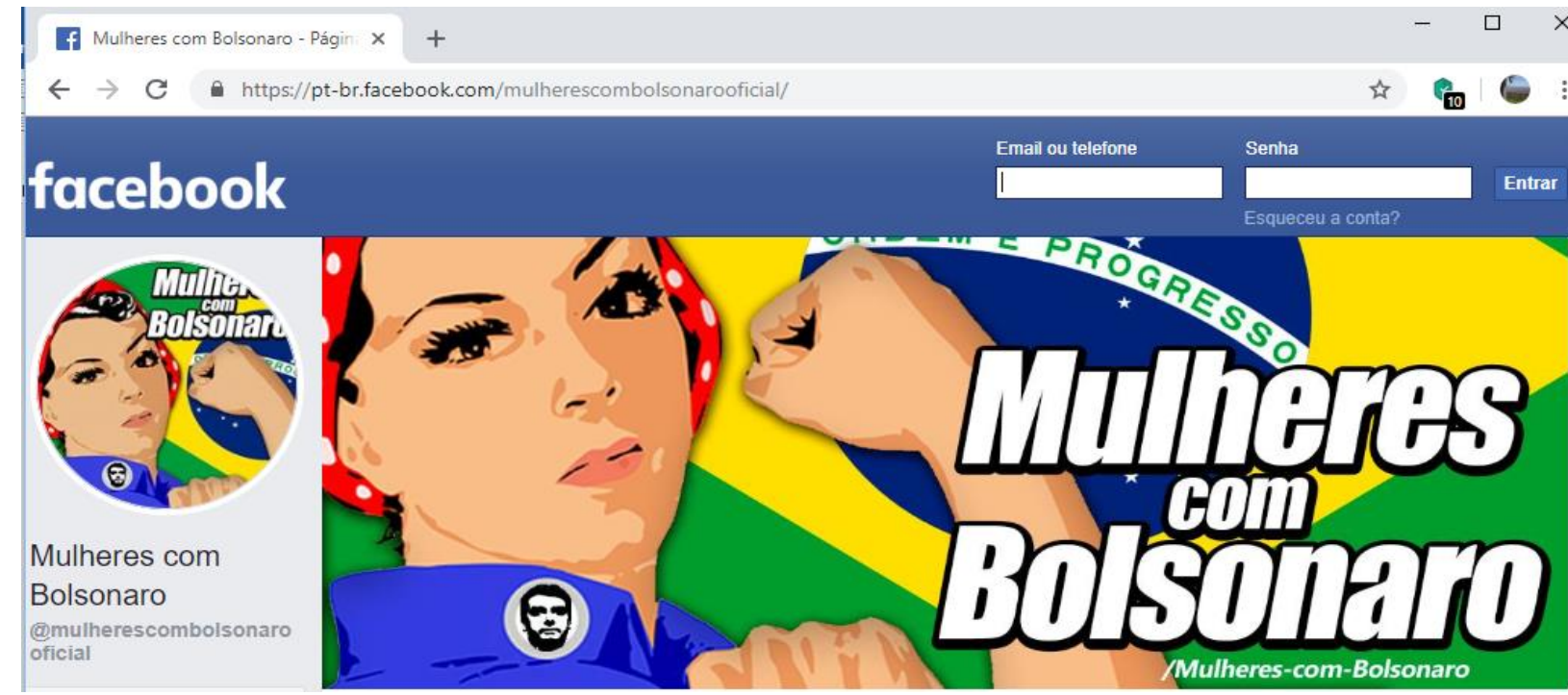

Imagem 2: Página de abertura da página "Mulheres com Bolsonaro" Fonte: Facebook

Um fato marcante é que, contrárias, ou favoráveis a candidatura de Jair Bolsonaro, as campanhas não ficaram restritas a internet, mas, através dela, houve a convocação para que mulheres comparecessem as manifestações de rua, nas principais cidades do país, e em algumas no exterior.

No dia 29 de setembro houve manifestação de mulheres contrárias a candidatura de Jair Bolsonaro, em 114 cidades do país e, também no exterior como em Lisboa, Londres, Nova York e Paris (ROSSI; CARNEIRO; GRAGNANI, 2018).

No mesmo dia e no dia seguinte, 30 de setembro, houve manifestações favoráveis ao candidato do PSL. Entre outras cidades essas manifestações aconteceram em São Paulo, Belo Horizonte, Salvador, Vitória e Porto Alegre (UOL, 2018). 


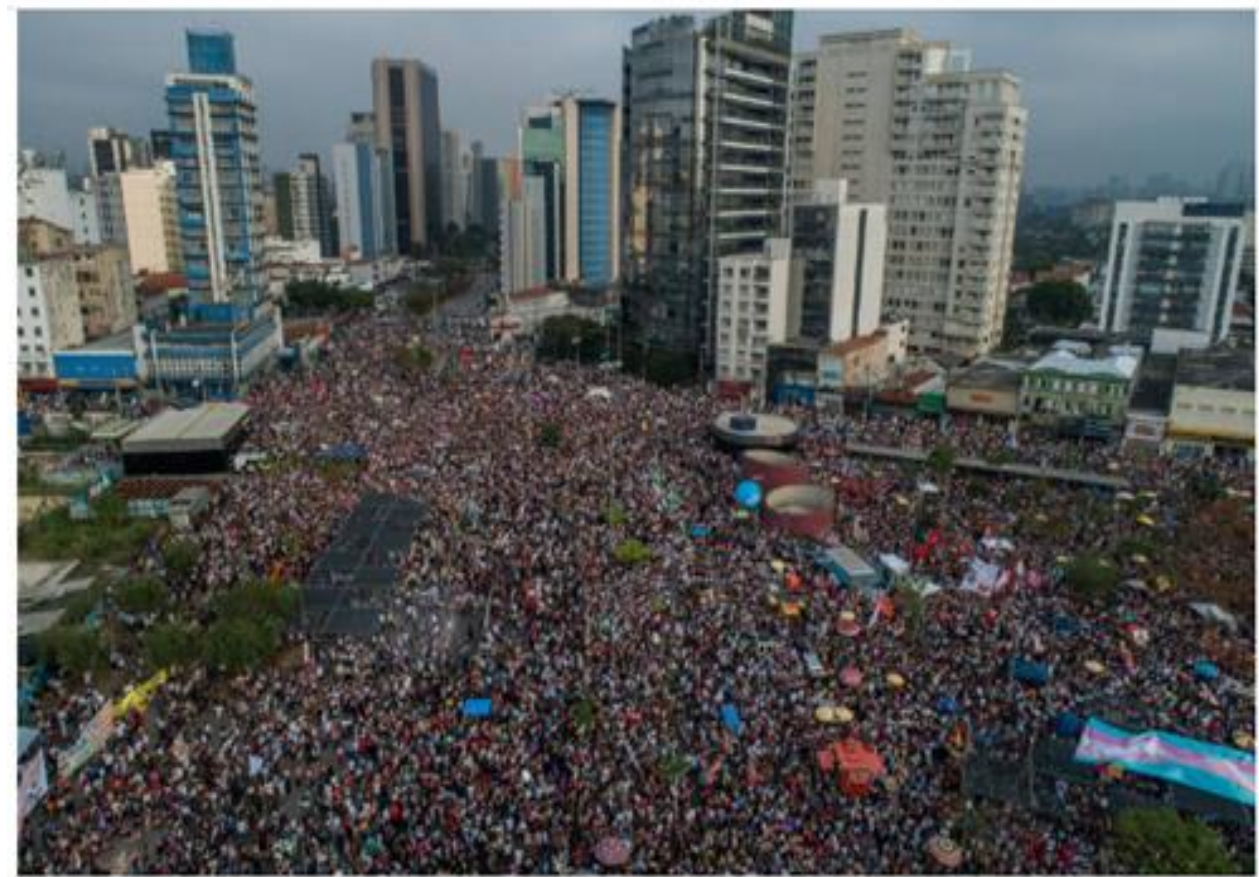

Ato contra o candidato a Presidència do PSL, Jair Bolsonaro, no largo da Batata, em Săo Paulo, neste sábado (29) - Eduardo Anizelli/ Folhapress

Imagem 3: Foto e legenda publicadas no site do Jornal Folha de São Paulo da manifestação contra Bolsonaro

Fonte: Folha de São Paulo

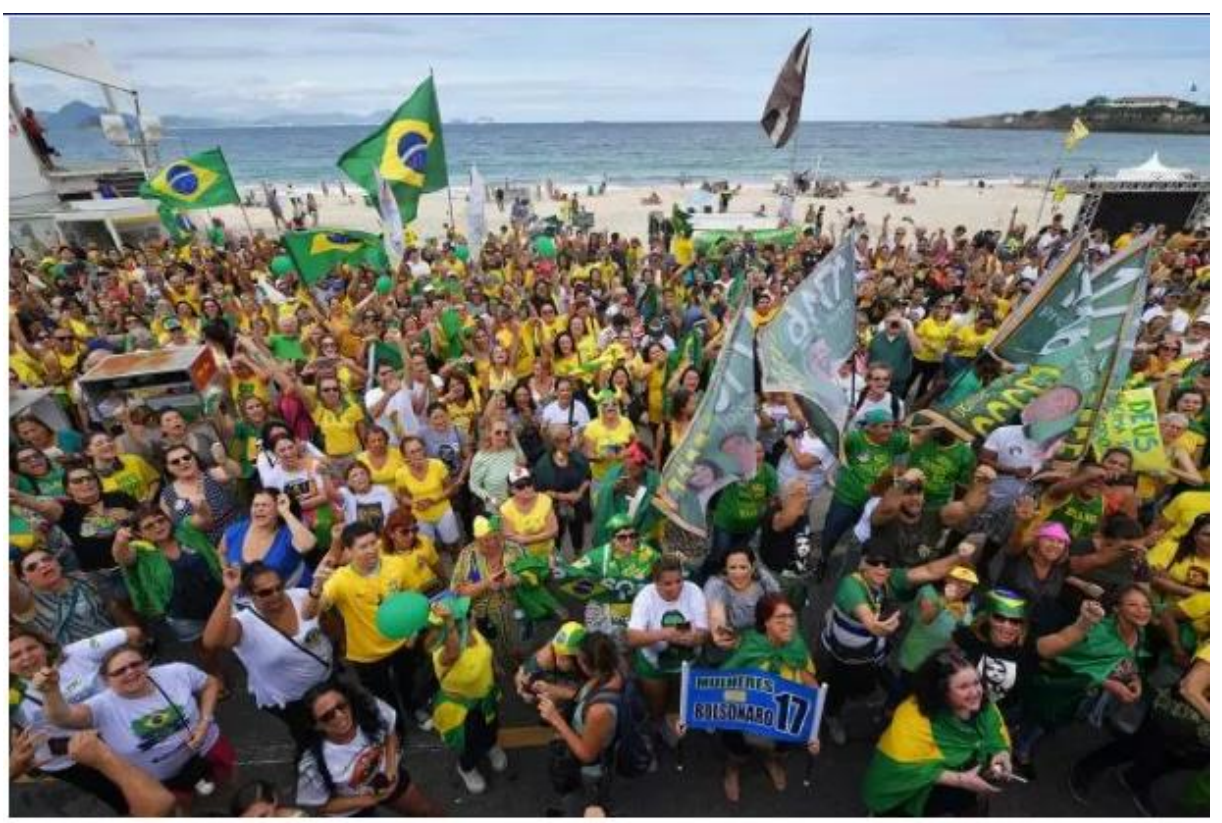

Apoiadores de Jair Bolsonaro realizam ato na praia de Copacabana, no Rio de Janeiro (Carl de Souza/AFP)

Imagem 4: Foto e legenda publicadas no site da Revista Veja da manifestação a favor de Bolsonaro

Fonte: Revista Veja 
Artigos | Gênero e cidadania: reflexões sobre a participação política das mulheres no processo eleitoral de 2018 no Brasil (MELO, Licemar Vieira; ALVES, Thaís da Rosa)

Contrárias ou favoráveis o fato é que houve um envolvimento político das mulheres, em torno das eleições, no Brasil; na internet ou nas ruas, elas assumiram publicamente seus posicionamentos políticos.

\section{As mulheres e a representatividade política na Câmara Federal}

O sufrágio feminino não fora suficiente para que as mulheres adentrassem de forma significativa nos espaços de poder e tivessem suas demandas atendidas de maneira satisfatória. Esta realidade, presente em diversos países do mundo, não é diferente no Brasil.

Embora o direito ao voto tenha sido conquistado pelas mulheres em 1932, é apenas no período de redemocratização que a presença das mulheres em espaços políticos passa a ser mais difundida com a criação de conselhos estaduais dos direitos das mulheres (MIGUEL, 2014).

Porém, mesmo assim, permaneceu baixa a presença das mulheres no Poder Legislativo. Como resposta, a lei de cotas é adotada como forma de garantir uma presença mínima de mulheres como parlamentares. No Brasil, a primeira eleição com a lei de cotas em vigor ocorreu em 2010, porém, não houve mudanças no número de mulheres eleitas com relação ao pleito anterior, em 2006, permanecendo 45 mulheres, ou seja, 9\% da Câmara Federal. Na eleição posterior, de 2014, o número subiu de 45 para 51, acarretando em um aumento de $1 \%$.

A primeira eleição em que houve o financiamento das campanhas eleitorais pelo Fundo Partidário e uma maior participação na propaganda política obrigatória das mulheres, representou um avanço no número de eleitas na Câmara Federal: passou de 51 para 77 cadeiras, um número ainda minoritário mas que representa um avanço de $50 \%$ em relação ao número de vagas até então ocupadas pelas mulheres em relação ao total de 513 cadeiras daquela casa legislativa - isso significa passar de 10\% para 15\%.

É preciso considerar, todavia que esse avanço não foi estendido para o Senado Federal, nem para os cargos de governadores dos Estados. No Senado houve apenas 7 senadoras eleitas, das 54 vagas em disputa. Como a renovação era de $2 / 3$ daquela casa legislativa, o número total de senadoras reduz de 13 , da legislatura anterior, para 12 , na legislatura que começa em 2019 (BRASIL, 2018). Já para o cargo de governador de 
Artigos | Gênero e cidadania: reflexões sobre a participação política das mulheres no processo eleitoral de 2018 no Brasil (MELO, Licemar Vieira; ALVES, Thaís da Rosa)

Estado, apenas uma mulher foi eleita, em $2018^{21}$, desempenho igual ao de 2014, mas inferior a 2006 - quando houve três governadoras eleitas - e a 2002 e 2010 quando houve duas governadoras eleitas.

Analisando apenas a Câmara Federal, a partir dos dados do Tribunal Superior Eleitoral (TSE), esse foi o melhor desempenho das mulheres, nas eleições, antes de 1986 o percentual não chegava a $2 \%$. Se for considerado apenas o período posterior a redemocratização é possível verificar o aumento da representatividade feminina nessa casa legislativa, embora isso não tenha ocorrido de forma contínua - verificar comparação entre os resultados das eleições de 1994 e 1998.

Quadro 1: Eleições de mulheres para a Câmara Federal no Brasil entre 1986 e 2018

\begin{tabular}{|l|l|l|l|}
\hline $\begin{array}{l}\text { Ano da } \\
\text { Eleição }\end{array}$ & $\begin{array}{l}\text { No de mulheres } \\
\text { eleitas na Câmara } \\
\text { Federal }\end{array}$ & $\begin{array}{l}\text { Total de } \\
\text { cadeiras Câmara } \\
\text { Federal }\end{array}$ & $\begin{array}{l}\% \\
\text { representativo } \\
\text { das mulheres }\end{array}$ \\
\hline 1986 & 29 & 487 & $6 \%$ \\
\hline 1990 & 30 & 503 & $6 \%$ \\
\hline 1994 & 33 & 513 & $6 \%$ \\
\hline 1998 & 28 & 513 & $5 \%$ \\
\hline 2002 & 43 & 513 & $8 \%$ \\
\hline 2006 & 45 & 513 & $9 \%$ \\
\hline 2010 & 45 & 513 & $9 \%$ \\
\hline 2014 & 51 & 513 & $10 \%$ \\
\hline 2018 & 77 & 513 & $15 \%$ \\
\hline
\end{tabular}

Fonte: Câmara dos Deputados ${ }^{22}$

Porém, este aumento de mulheres na Câmara de Deputados nas eleições de 2018 pode não ter sido apenas fruto do financiamento de suas campanhas e tempo de propaganda obrigatória. Ao verificarmos os partidos com maior número de mulheres eleitas, o então desconhecido PSL - partido pelo qual o presidente Bolsonaro se elegeu - possui 10 deputadas ${ }^{23}$.

\footnotetext{
${ }^{21}$ A candidata Fátima Bezerra do Partido dos Trabalhadores no Rio Grande do Norte.

22 Informações da Agência Câmara de Notícias, da Câmara dos Deputados brasileira. Disponível em: https://www.camara.leg.br/noticias/545897-bancada-feminina-na-camara-sobe-de-51-para-77deputadas/

${ }^{23}$ Foram eleitas 9 candidatas do PSL, porém, em 2019 a deputada Bia Kicis se filiou ao partido.
} 
Artigos | Gênero e cidadania: reflexões sobre a participação política das mulheres no processo eleitoral de 2018 no Brasil (MELO, Licemar Vieira; ALVES, Thaís da Rosa)

Com o mesmo número de eleitas está o Partido dos Trabalhadores (PT) - partido da ex-presidente Dilma Rousseff. Logo em seguida, como partidos que mais elegeram mulheres, estão o Partido Social Democrata Brasileiro (PSDB) com 9, Partido Liberal (PL) com 6, Partido Progressista (PP) com 5 e Partido Socialismo e Liberdade (PSOL) também com 5 .

Uma quantidade relevante de eleitas não possuía, até a campanha política, trajetórias político partidárias e tornaram-se reconhecidas através das suas redes sociais digitais. Parte das eleitas ganharam notoriedade a partir do processo de impeachment da presidente Dilma Rousseff, em 2016. Além de serem organizadoras de protestos contra a petista, muitas eram defensoras de pautas da ala conservadora, como a Escola Sem Partido ${ }^{24}$, o combate a corrupção, o acesso e porte de armas e a redução do Estado. Sendo assim, as mulheres da ala conservadora eleitas não possuíam pautas ligadas as demandas feministas.

Considerado pela mídia e por pesquisadores da política brasileira como o Congresso mais conservador dos últimos quarenta anos (QUEIROZ, 2018), nas eleições de 2018 também foram eleitas mulheres ligadas aos movimentos feministas e suas várias vertentes, como o feminismo negro ${ }^{25}$, além de, pela primeira vez na história contar com uma parlamentar indígena ${ }^{26}$.

Embora tenha-se uma bancada feminina maior, em termos quantitativos, do que os demais partidos políticos, dentro da Câmara, as mulheres são direcionadas para pautas voltadas para o social e cultural, como as que tratam da defesa dos direitos da mulher, idosos e deficientes. Já nas comissões principais, como a Comissão de Constituição e Justiça (CCJ) e Comissão de Finanças e Tributação (CFT), as mulheres possuem uma participação pequena, de $4,3 \%$ a 3,8\%, respectivamente (BOLDRINI,

\footnotetext{
24 O Escola Sem Partido é um movimento formado em 2004 que combate o que eles denominam como "doutrinação ideológica" nas salas de aula das escolas brasileiras. Tais ideias passaram a ser difundidas a partir de 2015 quando começaram a surgir projetos de lei em âmbitos municipais e estaduais baseados nas diretrizes deste grupo. Nas eleições de 2018, alguns candidatos, incluindo mulheres, eram responsáveis por este movimento em seus estados.

25 Áurea Coralina (PSOL/ MG), cientista política, vereadora mais votada em Belo Horizonte em 2016 e Talíria Petrone (PSOL/RJ), professora, vereadora eleita no Rio de Janeiro em 2016.

${ }^{26}$ A deputada federal Joênia Wapichana (REDE/RR).
} 
Artigos | Gênero e cidadania: reflexões sobre a participação política das mulheres no processo eleitoral de 2018 no Brasil (MELO, Licemar Vieira; ALVES, Thaís da Rosa)

2020). Com relação a lideranças, atualmente quatro bancadas possuem líderes mulheres: PSOL, REDE, PSL, Partido Comunista do Brasil (PCdoB) ${ }^{27}$.

Apesar da conquista de mais espaço na Câmara Federal, será preciso acompanhar na próxima legislatura, os projetos apresentados por essas parlamentares e perceber se os mesmos, efetivamente, vão contribuir para a implementação de políticas públicas para as mulheres e o combate as desigualdades de gênero, no país, em qualquer perspectiva - as questões relativas ao trabalho e renda podem ser inseridas nesse contexto.

\section{Considerações Finais}

Depois de trazer breves apontamentos teóricos sobre a cidadania, a participação política feminina no Brasil e analisar a participação das mulheres no processo eleitoral de 2018 defende-se que essa participação seja analisada pelo viés da cidadania, como um amplo exercício da mesma.

Se forem consideradas as mulheres, enquanto eleitoras, elas fizeram uso do direito político - origem da cidadania - de participarem do processo eleitoral, através do exercício do voto, mas, antes dele, de se posicionarem politicamente e livremente expressarem suas opiniões, através da internet, ou da participação em manifestações, nas ruas - a liberdade de expressão e de opinião é um direito civil, que também integra a cidadania (CERQUIER-MANZINI, 2010; LUNARDI E SECCO, 2010; PACHECO, 2003; PINSKY e PINSKY, 2010).

Por outro lado, se o olhar se voltar para o aumento da representatividade política das mulheres, na Câmara dos Deputados, é preciso considerar que o exercício da cidadania não se dá apenas no momento de participar das eleições, através do voto, ou no caso das eleições de 2018 , da participação, durante a campanha eleitoral "mas na possibilidade de participar na comunidade da tomada de decisões que irradiam efeitos sobre os interesses individuais, coletivos e ou difusos" (LUNARDI e SECCO, 2010, p. 204). E a Câmara dos Deputados representa esse local de tomada de decisões.

\footnotetext{
${ }^{27}$ São elas: Fernanda Melchionna (PSOL/RS); Joênia Wapichana (REDE/RR); Joice Hasselmann (PSL/SP); Perpétua Almeida (PCdoB/AC).
} 
Artigos | Gênero e cidadania: reflexões sobre a participação política das mulheres no processo eleitoral de 2018 no Brasil (MELO, Licemar Vieira; ALVES, Thaís da Rosa)

Tanto na perspectiva delas, enquanto eleitoras, ou enquanto representantes políticas a mudança de paradigma é evidente: se na Grécia Antiga, berço da democracia direta e dos primeiros exercícios de cidadania as mulheres eram representadas pelos homens livres, nas Assembleias e, portanto, não tinham voz, hoje elas mesmas tomam os seus lugares e conquistam os seus espaços na arena política, como no caso brasileiro.

Ainda se está longe de chegar a igualdade de gênero, no Brasil, em muitos aspectos, inclusive no de representatividade política, já que as mulheres representam cerca de $52 \%$ da população brasileira, segundo estimativa do Instituto Brasileiro de Geografia e Estatística (IBGE), de 2015, e, em termos de Câmara Federal, por exemplo, elas ocupem 15\%, considerando os avanços no pleito de $2018^{28}$.

Esse aumento da representatividade política feminina - de 10 para $15 \%$ da Câmara Federal - como demonstrado nesse trabalho, pode ser avaliado como um avanço, mas está muito aquém da média registrada nos parlamentos latino-americanos e do Caribe, que chega a aproximadamente $29 \%{ }^{29}$.

Sobre a participação política das mulheres, a partir das eleições de 2018, é preciso aguardar e acompanhar se o aumento da presença feminina nesse espaço de poder político que é a Câmara Federal, vai implicar em avanços nas lutas das mulheres em torno do combate as desigualdades de gênero, nos seus aspectos sociais e culturais, além do combate a violência contra a mulher no país. Quando forem percebidos esses avanços a cidadania poderá ser vivenciada em outro patamar, pelas mulheres, no Brasil.

Algumas demonstrações, todavia, já foram sentidas, no primeiro ano do exercício de mandato delas, na Câmara Federal. Um exemplo disso foi a articulação da bancada feminina pela derrubada do veto do Presidente da República, Jair Bolsonaro, ao Projeto de Lei que define o prazo de 24 horas para a rede de saúde pública ou privada comunicar à polícia caso em que houver indício ou confirmação de violência contra a mulher (SADI, 2019).

\footnotetext{
${ }^{28}$ Além do percentual de mulheres eleitas para a Câmara dos Deputados, em 2018, é necessário verificar, a partir de um estudo específico, se o perfil da maioria das deputadas federais eleitas em 2014 - alta escolaridade, profissionais liberais, com idade acima de 41 anos - como apontado por Resende e Epitácio (2017), também se reproduz na bancada feminina da atual legislatura.

${ }^{29}$ Informações da Agência Câmara de Notícias, da Câmara dos Deputados brasileira. Disponível em: https://www.camara.leg.br/noticias/545897-bancada-feminina-na-camara-sobe-de-51-para-77deputadas/
} 
Artigos | Gênero e cidadania: reflexões sobre a participação política das mulheres no processo eleitoral de 2018 no Brasil (MELO, Licemar Vieira; ALVES, Thaís da Rosa)

Somam-se a esta articulação, outras ações relacionadas a reforma da previdência votada em 2019, na qual a bancada feminina conseguiu diminuir o tempo inicial de contribuição para o acréscimo de benefício do INSS de 20 para 15 anos, além de proteger os direitos relacionados à maternidade e a pensão por morte, garantindo um salário mínimo para as dependentes que não possuem um emprego formal (FERNANDES, 2019).

Sobre o estabelecimento de cota de gênero no país, cabe ratificar que a mesma representa um avanço na conquista dos direitos políticos, para as mulheres. Entretanto o estabelecimento de uma cota mínima de 30\% de candidaturas, nas eleições, que está sendo destinada as mulheres, no Brasil, não corresponde, efetivamente, a destinação de $30 \%$ das vagas na Câmara dos Deputados para uma bancada feminina.

A questão da destinação do fundo partidário e do tempo de propaganda de rádio e televisão, para as candidatas mulheres, grande novidade nas eleições de 2018, também representam um avanço, porém, esse aspecto precisa ser melhor avaliado, no sentido de se verificar se foi cumprida a finalidade de garantir igualdade de condições para as candidatas concorrerem naquele pleito.

A observação acima é importante pois a partir de fevereiro de 2019 a Polícia Federal começou a investigar denúncias que envolviam candidatas que disputavam vaga para a Assembleia Legislativa e para a Câmara Federal pelo Partido Social Liberal (PSL), pelo estado de Minas Gerais. Segundo denúncias essas candidatas teriam recebido esses recursos e foram coagidas a desviar parte deles destinando-os a empresas ligadas aos assessores do então Presidente do Diretório Estadual do PSL, em Minas Gerais, Marcelo Álvaro Antônio, que foi reeleito Deputado Federal, em 2018, e nomeado Ministro do Turismo pelo Presidente Jair Bolsonaro. Além do Presidente do Diretório Estadual do PSL em Minas Gerais, um Deputado Estadual e outras nove pessoas foram indiciadas pela Polícia Federal, em outubro de 2019, denunciados pelos crimes de falsidade ideológica eleitoral, apropriação indébita eleitoral e associação criminosa. Esse fato corrobora a utilização de mais um artifício que contribui para a perpetuação da desigualdade de condições de participação das mulheres nas disputas eleitorais (ERNESTO, 2019).

Em relação à desigualdade de gênero, segundo dados de 2016 e 2017 do Instituto Brasileiro de Geografia e Estatística (IBGE), divulgados em 2018, as mulheres 
Artigos | Gênero e cidadania: reflexões sobre a participação política das mulheres no processo eleitoral de 2018 no Brasil (MELO, Licemar Vieira; ALVES, Thaís da Rosa)

estudam mais, já que cerca de 35\% delas, com 25 anos ou mais, tem nível superior, contra $28 \%$ dos homens, na mesma faixa etária; já quando o aspecto observado é a remuneração elas, exercendo a mesma função que os homens, recebem cerca de $25 \%$ a menos, além de serem recordistas em tempo parcial de trabalho pois, como corrobora a pesquisa, são as mulheres que conciliam afazeres domésticos com o trabalho remunerado (IBGE, 2018).

Já sobre o combate a violência contra a mulher, é pertinente considerar as altas taxas de feminicídio no Brasil, que correspondente ao assassinato de mulheres em função do gênero, o que pela Lei Federal 13.104/15 passou a ser considerado crime hediondo. Segundo dados do Anuário Brasileiro de Segurança Pública (2018), publicado pela ONG Fórum Brasileiro de Segurança Pública, se em 2016 foram registrados, entre as mulheres que sofriam violência doméstica, 929 casos de feminicídio, no país, em 2017 esse número aumentou para 1.133.

Em consonância com este cenário, 77 mulheres ocuparam as cadeiras da Câmara de Deputados, o maior número de eleitas desde 1986. Porém, ao analisarmos o perfil das deputadas e suas trajetórias pré-eleições, não podemos afirmar que uma maior presença garantirá uma maior sensibilidade às demandas pautadas pelos movimentos feministas no Brasil.

A onda conservadora que chegou aos poderes Executivo e Legislativo nas eleições de 2018 possuem um discurso no qual o papel da mulher é subsumido ao seu lugar na família, descartando algumas discussões já consideradas de difícil acesso ao plenário como a questão do aborto, por exemplo, o que nos faz refletir até que ponto a presença das mulheres corresponde a uma verdadeira representação.

As eleições de 2018, todavia, também trouxeram algumas inovações em âmbito estadual que podem servir de exemplo para as próximas eleições no âmbito federal, como os mandatos coletivos. Com o intuito de descentralizar a representação individual, duas candidaturas foram eleitas dessa forma, em São Paulo a Bancada Ativista ${ }^{30}$

\footnotetext{
${ }^{30}$ Composto por Mônica Seixas, advogada negra feminista; Anne Rammi, ativista ligada à maternidade; Chirley Pankará, pedagoga indígena; Claudia Visoni, jornalista e ambientalista; Erika Hilton mulher negra trans e ativista pelos direitos humanos; Fernando Ferrari, militante contra o genocídio da juventude periférica; Jesus dos Santos, migrante nordestino, militante do movimento negro; Paula Aparecida, mulher negra, professora da rede pública e feminista e, Raquel Martins, sanitarista e ativista pela humanização do parto.
} 
Artigos | Gênero e cidadania: reflexões sobre a participação política das mulheres no processo eleitoral de 2018 no Brasil (MELO, Licemar Vieira; ALVES, Thaís da Rosa)

(PSOL/SP), formada por 7 mulheres e 2 homens e em Pernambuco o Juntas ${ }^{31}$ (PSOL/PE) formado por 5 mulheres. Também houve em São Paulo, a eleição da primeira mulher negra transgênero, a deputada Erica Malunguinho (PSOL/SP) com a sua mandata quilombo, demonstrando assim uma nova forma de se pensar a representatividade política e enfrentar possíveis retrocessos no campo dos direitos destes grupos.

\section{Referências}

ALVAREZ, Sonia E. Politizando as relações de gênero e engendrando a democracia. In: STEPAN, A. (Org.) Democratizando o Brasil. Rio de Janeiro: Paz e Terra, 1988, pp. 315-380.

ALVES, José Eustáquio Diniz et al. Meio século de feminismo e o empoderamento das mulheres no contexto das transformações sociodemográficas do Brasil. In: BLAY, Eva Alterman; AVELAR, Lúcia (Org.). 50 anos de feminismo: Argentina, Brasil e Chile: A construção das mulheres como atores políticos e democráticos. São Paulo: Editora da Universidade de São Paulo, Fapesp, 2017, p. 15-54.

ALVES, Thaís da Rosa. Entre a política e o movimento: as concepções e as práticas políticas de mulheres negras no Morro da Polícia/ Porto Alegre. 2018, 119 f. Dissertação (Mestrado em Ciências Sociais). Curso de Pós-Graduação em Ciências Sociais, Universidade do Vale do Rio dos Sinos (UNISINOS), São Leopoldo, 2018. Disponível em: http://www.repositorio.jesuita.org.br/bitstream/handle/UNISINOS/6992/Thais\%20da\%20Rosa \%20Alves .pdf?sequence=1\&isAllowed=y. Acesso em: 3 maio 2020.

ARISTÓTELES. A Política. - 2a Ed. - São Paulo: Martins Fontes, 1998.

ASSEMBLEIA NACIONAL CONSTITUINTE. Declaração dos direitos do homem e do cidadão. Adotada e proclamada pela Assembleia Nacional Constituinte da França em 26 de agosto de 1789, São Paulo: Biblioteca Virtual de Direitos Humanos, [2018?]. Disponível em: http://www.direitoshumanos.usp.br/index.php/Documentos-anteriores-\%C3\%A0cria\%C3\%A7\%C3\%A3o-da-Sociedade-das-Na\%C3\%A7\%C3\%B5es-at\%C3\%A9-1919/declaracaode-direitos-do-homem-e-do-cidadao-1789.html. Acesso em: 19 dez. 2018.

AVELAR, Lúcia; RANGEL, Patrícia. Como as mulheres se representam na política? Os casos de Argentina e Brasil. In: BLAY, Eva Alterman; AVELAR, Lúcia (Org.). 50 anos de feminismo: Argentina, Brasil e Chile: A construção das mulheres como atores políticos e democráticos. São Paulo: Editora da Universidade de São Paulo, Fapesp, 2017, p. 255-300.

BECKER, Fernanda. \#EleNão: após tomar as redes, movimento liderado por mulheres contra Bolsonaro testa forças nas ruas. El País, São Paulo, 30 set. 2018. Disponível em: https://brasil.elpais.com/brasil/2018/09/26/politica/1537989018 413729.html. Acesso em: 26 mar. 2019.

BLAY, Eva Alterman. A Participação das mulheres na redemocratização. In: Fleischer, David. (org.). Da distensão a abertura: as eleições de 1982. Brasília: Editora da UnB, 1988, p. 185-206.

Como as mulheres se construíram como agentes políticas e democráticas: o caso brasileiro. In: BLAY, Eva Alterman; AVELAR, Lúcia (Org.). $\mathbf{5 0}$ anos de feminismo: Argentina, Brasil e Chile: A construção das mulheres como atores políticos e democráticos. São Paulo: Editora da Universidade de São Paulo, Fapesp, 2017, p. 65-97.

\footnotetext{
${ }^{31}$ Formado por Carol Vergulino, jornalista; Joelma Carla, estudante de Letras; Jô Lima, ambulante; Kátia Cunha, professora e, Robeyoncé Lima mulher trans advogada.
} 
Artigos | Gênero e cidadania: reflexões sobre a participação política das mulheres no processo eleitoral de 2018 no Brasil (MELO, Licemar Vieira; ALVES, Thaís da Rosa)

BOLDRINI, Angela. Maior, bancada feminina enfrenta barreiras. Zero Hora, Porto Alegre, 08 de mar. De 2020. Disponivel em: https://gauchazh.clicrbs.com.br/politica/noticia/2020/03/maior-bancada-feminina-enfrentabarreiras-ck7j21bmh01g601qpop9vqivi.html. Acesso em: 03 maio 2020.

BONETTI, Alinne de Lima; FONTOURA, Natália; MARINS, Elizabeth. Sujeito de direitos? Cidadania feminina nos vinte anos da constituição cidadã. In: Instituto de Pesquisa Econômica Aplicada (IPEA). Políticas Sociais: acompanhamento e análise. Brasília- DF, v. 3, n. 14, p. 199257, 2009.

BOURDIEU, Pierre. Sobre o Estado: Cursos no Collège de France (1989-92). Trad. Rosa Freire dÁguiar. São Paulo: Companhia das Letras, 2014.

BRASIL. Senado Federal. Com sete senadoras eleitas, bancada feminina no Senado não cresce. Brasília, DF: Senado Federal, 2018. Disponível em: https://www12.senado.leg.br/noticias/materias/2018/10/08/com-sete-senadoras-eleitasbancada-feminina-no-senado-nao-cresce. Acesso em: 17 dez. 2018.

CERQUIER-MANZINI. Maria Lourdes. O que é cidadania. 4. Ed. - São Paulo: Brasiliense, 2010.

CUCHET, Violaine Sebillotte. Cidadãos e cidadãs na cidade grega clássica. Onde atua o gênero? In: Revista Tempo, Revista Digital do Programa de Pós-graduação em História da Universidade Federal Fluminense (UFF) vol. 21, n 38, Niterói-RJ, 2015. Pág. 281 a 300. Disponível em: < http://www.scielo.br/pdf/tem/v21n38/1413-7704-tem-21-38-00281.pdf>

DECLARAÇÃO UNIVERSAL DOS DIREITOS DO HOMEM E DO CIDADÃO. Assembleia Nacional da França, $1789 . \quad$ Disponível em: http://www.direitoshumanos.usp.br/index.php/Documentos-anteriores-\%C3\%A0cria\%C3\%A7\%C3\%A3o-da-Sociedade-das-Na\%C3\%A7\%C3\%B5es-at\%C3\%A9-1919/declaracaode-direitos-do-homem-e-do-cidadao-1789.html . Acesso: 26 mar. 2019.

EINSENBERG, José. Ciberativismo. In: GIOVANNI, Geraldo Di \& NOGUEIRA, Marco Aurélio (Org.). Dicionário de Políticas Públicas. 2v. São Paulo: Fundap / Imprensa oficial, 2015.

ERNESTO, Marcelo. MP de Minas denuncia ministro do Turismo e mais 10 por candidaturas laranjas em 2018. Estado de Minas, Belo Horizonte, 4 out. 2019. Disponível em: https://www.em.com.br/app/noticia/politica/2019/10/04/interna politica,1090330/mp-deminas-denuncia-ministro-do-turismo-e-mais-10-por-candidaturas-l.shtml. Acesso em: 20 nov. 2019.

FERNANDES, Marcella. O primeiro ano da maior bancada feminina da Câmara dos Deputados. Huffpost Brasil, São Paulo, 21 de dez. de 2019. Disponível em: https://www.huffpostbrasil.com/entry/2019-bancadafeminina br 5df93d04e4b08083dc5a7765. Acesso em 03 maio 2020.

FÓRUM BRASILEIRO DE SEGURANÇA PÚBLICA. Anuário Brasileiro de Segurança Pública 2018. Relatório de Pesquisa. São Peulo, 2018. Disponível em: http://www.forumseguranca.org.br/wp-content/uploads/2019/02/Anuario-2019-v6infogr\%C3\%A1fico-atualizado.pdf. Acesso em: 25 de mar. 2019.

FUNDAÇÃO INSTITUTO BRASILEIRO DE GEOGRAFIA E ESTATÍSTICA (IBGE). Mulher estuda mais, trabalha mais e ganha menos do que o homem. Rio de Janeiro: IBGE, 2018. Disponível em: https://agenciadenoticias.ibge.gov.br/agencia-noticias/2012-agencia-denoticias/noticias/20234-mulher-estuda-mais-trabalha-mais-e-ganha-menos-do-que-o-homem. Acesso em: 25 mar. 2019.

GIDDENS, A. A terceira via: reflexões sobre o impasse político atual e o futuro da socialdemocracia. Rio de Janeiro: Record, 2001.

JELIN, Elizabeth. Mulheres e direitos humanos. Revista Estudos Feministas, Florianópolis, v. 2, n. 1, p. 117-149, 1994.

KLIKSBERG, B. Repensando o Estado para o desenvolvimento social: superando dogmas e convencionalismos. 2 ed. São Paulo: Cortes, 2002. 
Artigos | Gênero e cidadania: reflexões sobre a participação política das mulheres no processo eleitoral de 2018 no Brasil (MELO, Licemar Vieira; ALVES, Thaís da Rosa)

LOZANO, Betty Ruth L. El feminismo no puede ser uno porque lãs mujeres somos diversas. Aportes a um feminismo negro decolonial desde la experiência de las mujeres del Pacífico colombiano. La manzana de la discórdia. Cali, v. 5, n. 2, p. 7-24, jul. - dez. 2010. Disponível em: http://manzanadiscordia.univalle.edu.co/index.php/la manzana de la discordia/article/view L1516. Acesso em: 4 maio 2020.

LUNARDI, G.; SECCO, M. (org). Fundamentação Filosófica dos Direitos Humanos. Florianópolis: Ed. Da UFSC, 2010.

MARTINS, Laís; BOADLE, Anthony. Saiba mais - veja algumas das declarações mais polêmicas de Bolsonaro. Agência de Notícias Reuters, São Paulo, 17 de maio de 2018. Disponível em: https://br.reuters.com/article/domesticNews/idBRKCN1II3OR-OBRDN. Acesso em: 14 dez. 2018.

MIGUEL, Luis Felipe. Gênero e representação política. In: MIGUEL, L. F. e BIROLI, F. Feminismo e política. São Paulo: Boitempo, 2014, pp. 89-103.

MOURA, Rafael Moraes; CURY, Teo. Mulheres ficarão com pelo menos $30 \%$ do fundo eleitoral e do tempo da propaganda, decide TSE. Estadão, São Paulo, 22 de maio de 2018. Disponível em: https://politica.estadao.com.br/blogs/fausto-macedo/mulheres-ficarao-compelo-menos-30-do-fundo-eleitoral-e-do-tempo-da-propaganda-decide-tse/. Acesso em: Acesso: 25 mar. 2019

NAÇÕES UNIDAS. Assembleia Geral. Declaração universal dos direitos humanos. Adotada e proclamada pela Assembléia Geral das Nações Unidas (resolução 217 A III) em 10 de dezembro 1948. Brasília, DF: ONU, [2018?]. Disponível em: https://nacoesunidas.org/wpcontent/uploads/2018/10/DUDH.pdf. Acesso em: 19 dez. 2018.

PACHECO, Ricardo de Aguiar. De Escravo a não-consumidor: as representações sociais acerca da cidadania no Ocidente e o cidadão brasileiro. In: BILHÃO, Isabel (org). Visões do Brasil: realidade e perspectivas. Caxias do Sul: EDUCS, 2003.

PINHEIRO-MACHADO, Rosana; BURIGO, Joanna. \#Elenão deixou de ser uma simples hashtag: é um movimento feminista e político que pode mudar o Brasil. The Intercept Brasil, São Paulo, 28 set. 2018. Disponível em: <https://theintercept.com/2018/09/28/elenaomovimento-feminista-politico/>. Acesso em: 20 nov. 2018.

PINSKY, Jaime; PINSKY. Carla Bassanezi. História da Cidadania. 5a Ed. - São Paulo: Contexto, 2010.

QUEIROZ, Antônio Augusto de. O congresso mais conservador dos últimos quarenta anos. Le Monde Diplomatique Brasil, São Paulo, 05 de nov. de 2018. Disponível em: https://diplomatique.org.br/o-congresso-mais-conservador-dos-ultimos-quarenta-anos/.

Acesso em 04 maio 2020.

RESENDE, Roberta Carnelós; EPITÁCIO, Sara. Mulheres à esquerda e à direita: carreiras políticas e partidos políticos. Mediações - Revista de Ciências Sociais, v. 22, p. 350-355, 2017.

ROSSI, Amanda; CARNEIRO, Julia Dias; GRAGNANI, Juliana. \#EleNão: a manifestação histórica liderada por mulheres no Brasil vista por quatro ângulos. BBC Brasil, São Paulo, 30 set. 2018. Disponivel em: https://www.bbc.com/portuguese/brasil-45700013. Acesso em: 17 dez. 2018.

SADI, Andréia. Maia e deputadas articulam derrubar veto de Bolsonaro em lei sobre violência contra a mulher. In: SADI, Andréia. Blog da Andréia Sadi. Rio de Janeiro, 14 out. 2019. Disponível em: https://g1.globo.com/politica/blog/andreia-sadi/post/2019/10/14/maia-edeputadas-articulam-derrubada-de-veto-a-prazo-de-24-horas-para-notificacao-de-violenciacontra-mulher.ghtml. Acesso em: 20 nov. 2019.

SCOTT, Joan. Gênero: uma categoria útil para análise histórica. Educação e realidade,

Porto Alegre, v. 20, n. 2, 1995, p. 71-99. Disponível em: http://www.seer.ufrgs.br/educacaoerealidade/article/view/71721/40667. Acesso em: 4 maio 2020. 
Artigos | Gênero e cidadania: reflexões sobre a participação política das mulheres no processo eleitoral de 2018 no Brasil (MELO, Licemar Vieira; ALVES, Thaís da Rosa)

SINGER, Paul. O feminino e o feminismo. In SINGER, P. e BRANT, V. (Orgs.). São Paulo: O povo em movimento. Petrópolis: Vozes; São Paulo: CEBRAP, 1980, pp. 109-142.

TOURAINE, Alain. 0 que é democracia? Trad. Guilherme João de Freitas Teixeira. Petrópolis: Vozes, 1996.

UOL. Em resposta ao \#EleNão, apoiadores de Bolsonaro promovem atos pelo país. In: Notícias UOL, São Paulo, 30 set. 2018. Disponível em: https://noticias.uol.com.br/politica/eleicoes/2018/noticias/2018/09/30/manifestacoes-apoiobolsonaro-varias-cidades-pais.htm. Acesso em: 17 dez. 2018. 